\title{
Physicochemical and sensory profile of rice bran roasted in microwave
}

\author{
Perfil físico-químico e sensorial de farelos de arroz torrados em micro-ondas
}

Marina Costa GARCIA ${ }^{1 \star}$, Marta de Toledo BENASSI ${ }^{2}$, Manoel Soares SOARES JÚNIOR ${ }^{1}$

\begin{abstract}
The purpose of this study was to evaluate the physical, chemical, and sensory changes in bran from three rice cultivars according to microwave roasting time. This study analyzed three rice cultivars, BRS Sertaneja (S), BRS Primavera (P), and IRGA 417 (I) determining the color parameters $\left(\mathrm{L}^{*}, \mathrm{a}^{*}\right.$, and $\left.\mathrm{b}^{*}\right)$ at $6,9,12,15$, and 18 minutes of roasting time. After applying the difference from control test, the rice brans with different characteristics aroma and flavor were selected: $\mathrm{S}$ and P roasted for 9 and 15 minutes and IRGA 417 roasted for 9,12 , and 15 minutes. These samples were characterized by Free-Choice Profile descriptive sensory analysis, and their chemical composition was also determined. The longer the roasting process, the higher the roasted flavor intensity and aroma. The IRG 417 cultivar roasted for 12 minutes showed a sweeter flavor and aroma. After roasting, the brans remained rich in protein and lipid and presented higher fiber content and lower reducing sugar and phytic acid content. Microwave roasting for 12 minutes can be a viable option for improving the sensory functional and nutritional characteristics of the rice bran considering its use in food products.
\end{abstract}

Keywords: Oryza sativa L.; cultivar; byproduct; color; free-choice profile; phytic acid.

\section{Resumo}

Este trabalho objetivou avaliar as mudanças físicas, químicas e sensoriais de farelos de três cultivares de arroz em função do tempo de torra em micro-ondas. Foram estudados 3 cultivares de arroz, BRS Sertaneja (S), BRS Primavera (P) e Irga 417 (I), determinando-se os parâmetros de $\operatorname{cor}\left(\mathrm{L}^{*}, \mathrm{a}^{*}\right.$ e b*) aos 6, 9, 12, 15 e 18 minutos de torração. Após aplicação do teste de diferença do controle, selecionaram-se farelos de arroz com características de sabor e aroma distintas: S e P torrados por 9 e 15 minutos e I torrado por 9, 12 e 15 minutos. Essas amostras foram caracterizadas pela análise sensorial descritiva de Perfil Livre e quanto à composição química. Quanto mais longa a torração, mais intenso o aroma e sabor de torrado dos farelos, apresentando sabor e aroma mais doce o da IRGA 417 torrado por 12 minutos. Após a torração, o farelo continuou um alimento rico em proteínas e lipídios, aumentou o conteúdo de fibra e diminuiu o teor de açúcares redutores e ácido fítico. O farelo de arroz torrado por 12 minutos em micro-ondas pode ser uma opção viável para melhorar as características sensoriais, funcionais e nutricionais do farelo de arroz.

Palavras-chave: Oryza sativa; cultivar; subproduto; cor; perfil livre; ácido fítico.

\section{Introduction}

In Brazil, there are two basic systems of rice cultivation: irrigated with high technology and productivity, and highlands, with lower productivity, but which has been showing significant technological development in the last years. It has also showed good grain quality and the same market classification as that the irrigated rice. Both floodplain ecosystem, under irrigated cropping system, and highland upland, under dryland cropping system, play an important role in rice production in Brazil. Among the dryland rice cultivars in Brazil, currently known as highland rice, BRS Primavera and BRS Sertaneja feature long and thin grains. IRGA 417 cultivar is an irrigated cropping plant that can be also characterized as long and thin grains with high amylose content.

Rice bran, a by-product of rice milling processing, is the outer layer of the grain, which consists of the pericarp and aleurone, totaling close to $10 \%$ of the whole product weight.
Rice bran nutritional quality ranges considerably due to genetic factors (thickness of anatomical layers, size, shape, and resistance to grain breakage), soil and climatic conditions, use of fertilizers and processing conditions (drying temperature, moisture content during processing, and polishing degree), and storage (ABDUL-HAMID et al., 2007). Rice bran is rich in protein, fiber, lipids, and antioxidant compounds, but despite its potential as raw material for preparation of functional foods, it is still underused in human food (PARRADO et al., 2006). Antinutritional factors, such as trypsin inhibitor and lectins, are inactivated by heat, and therefore are not present in the roasted product (OATWAY; VASANTHAN; HELM, 2001; HAN et al., 1994).

One of the limitations to the use of rice bran is its quick degradation after processing due to hydrolytic and oxidative rancidity of lipids (FEDDERN; FURLONG; SOARES, 2007).

\footnotetext{
Received 7/3/2012

Accepted 10/7/2012 (005624)

${ }^{1}$ School of Agronomy and Food Engineering, Federal University of Goiás - UFG, Rod. GO-462, Km 0, CP 131, Campus Samambaia, CEP 74690-900, Goiânia, GO, Brazil,

e-mail: marinacosta16@gmail.com

${ }^{2}$ Department of Food Science and Technology, State University of Londrina - UEL, CP 6001, CEP 86051-970, Londrina, PR, Brazil

${ }^{*}$ Corresponding author
} 
The inactivation of the enzymes accountable for rancidity (lipoxygenases and lipases) is usually performed using the roasting procedure (SAUNDERS, 1990). The stabilization process by heating in microwave for 3 minutes did not affect the main nutrients of rice bran. However, aromas are developed in the roasting process, mainly caused by the formation of compounds of the Maillard reaction. Moreover, among its various end products are the melanoidins, which are responsible for color, aroma, and antioxidant activity of many foods (RAMEZANZADEH et al., 2000; ABDUL-HAMID et al., 2007).

The descriptive sensory analysis of roasted brans from different cultivars enables to evaluate the effect of roasting process on the sensory characteristics of the products. The Free-Choice Profile is based on the principle that people perceive the same characteristics in a product even though they express themselves differently. Each panelist is allowed to use his/her own unique list of terms to evaluate the products. The results were evaluated by the Generalized Procrustes Analysis (GPA), which eliminates variations in the description of samples allowing detecting differences in perception by the panelists and/or lack of repeatability (MURRAY; DELAHUNTY; BAXTER, 2001).

Thus, the purpose of this study was to study the physical and chemical (color, water activity, proximate composition and reducing sugars, and phytic acid contents) and sensory characteristics of rice bran from three cultivars (BRS Sertaneja, BRS Primavera, and IRGA 417) submitted to microwave roasting. This information can help increase the use of rice bran in the formulation of food for human consumption.

\section{Material and methods}

\subsection{Raw material}

Three rice cultivars BRS Sertaneja (S), BRS Primavera (P), and IRGA 417 (I) were used for bran extraction using a rice processor (Satake Rice, Embrapa, Brazil).

\subsection{Roasting process}

After sieving (Tyler 42) and before roasting, the bran moisture content was adjusted to $21 \mathrm{~g} / 100 \mathrm{~g}$ to accelerate the enzymatic inactivation during heat treatment, according to Ramezanzadeh et al. (2000).

The rice bran samples were roasted in batches of $150 \mathrm{~g}$ in a microwave oven (CCE, model M210, Brazil) with an internal volume of $21 \mathrm{~L}$, a cylindrical refractory glass $(4 \mathrm{~mm}$ thick and $260 \mathrm{~mm}$ in diameter in the center of the device), and power of $758 \mathrm{~W}$. During the roasting process, the bran was frequently homogenized at 1 minute intervals with a spoon to avoid burning and formation of hot spots.

The equipment was preheated for 3 minutes to establish a constant initial temperature and uniform the roasting conditions. The roasting times were predetermined in preliminary tests. Each cultivar underwent six roasting times: $0,6,9,12,15$, and 18 minutes (treatments) with three process repetitions. After the roasting process, the samples were kept at room temperature for 1 hour for cooling, and then they were vacuum-packed (Turbo Vac, 4155, Brazil) in a laminated film package (polyethylene/nylon/polyethylene) to prevent loss of aroma. The rice bran samples were stored at room temperature up to analysis. The experimental roasted brans were identified by the cultivar ( $\mathrm{S}, \mathrm{P}$, and $\mathrm{I}$ ) and a number corresponding to the roasting time $(6,9,12,15$, and 18 minutes $)$.

\subsection{Physical characteristics}

The analysis of instrumental color $\left(L^{*}, a^{*}\right.$, and $\left.b^{*}\right)$ was performed using a colorimeter (Byk Gardner GmbH, Wesel, Germany) with D65 illuminant and geometry 45/0. The water activity (Aw) was determined using the device Aqua Lab CX 10 (Decagon, Pullman, USA).

\subsection{Sensory evaluation}

The roasted rice bran samples were evaluated using a two step-sensory analysis. At first, the difference from control test was applied and secondly, the Free-Choice Profile analysis was used. The panelists were informed about the products and testing procedures, according to the research project approved by Ethics Committee of the Universidade Federal de Goiás (number 181/09).

All tests were performed in individual booths, and the samples were served at room temperature (5 g per sample) in transparent and disposable closed containers coded with three random digits. The presentation order of the samples was randomized for each panelist.

The research followed legal ethical aspects; the project was approved by the Ethics Committee of the Universidade Federal de Goiás (number 181/09).

\section{Difference from control test}

The difference from control test was applied to estimate the level of difference concerning aroma and taste between the standard sample, defined as the lowest roasting time (6 minutes), and the remaining roasted bran, to select differentiated samples for the descriptive test. A red light was used to mask color differences among the samples. A panel with 24 panelists was used. In each session (one per cultivar), each panelist received simultaneously the control sample (6 minutes) and coded samples corresponding to different roasting times $(6,9,12,15$ and 18 minutes). The panel was instructed to assess the level of difference between each sample and control using a five-point scale ranging from zero (no difference) to four (quite different).

\section{Free-Choice Profile analysis}

The Free-Choice Profiling was used to access two brans of BRS Sertaneja (S9 and S15), two of BRS Primavera (P9 and P15), and three of IRGA 417 (I9, I12 and I15), selected during the difference from control test. All analyses were performed under white light.

The panel was composed of ten panelists (three men and seven women) aged between 23 and 35 years. The panel was 
characterized by high educational level and had previous experience with sensory analysis. The Kelly repertory grid method (MOSKOWITZ, 1983) was used for development of the attributes. The samples were presented to the panel in pairs in four different sessions. Pair selection was based on the greatest difference between them. The panelists were asked to find as many differences and similarities between the pair of samples as possible, and they were encouraged to use whatever terms they wished to describe the samples. After this step, an individual discussion took place. Based on the individual descriptive forms, personalized score sheets and a glossary were prepared. Each assessor had his/her own glossary and score sheet containing the descriptive terms developed individually. To quantify each attribute, a hybrid intensity scale anchored with grades 0,5 , and 10 and the verbal terms at the end (KITZBERGER et al., 2010) was used.

A session simulating the presentation of the Free-Choice Profile was performed. The panelists evaluated three selected samples to assess the adequacy of the score sheets and were able to change the vocabulary (both the descriptors and the descriptors definition in the glossary). At each session, the panelists received a glossary with the score sheets. All the samples were assessed using a balanced incomplete block design for seven samples. Seven sessions were performed. At each session, the same block (three samples) was evaluated by each panelist totaling three replicate assessments for each sample. Monadic presentation was used.

\subsection{Chemical properties}

The approximate composition of raw and roasted rice bran was performed according to the methods of the Association of Official Analytical Chemists (1997); the total carbohydrate content was estimated by difference (BRASIL, 2003). The Somogyi (1945) and Nelson (1944) methods were applied to quantify the amount of reducing sugars. The extraction of phytic phosphorus followed the procedure described by Thompson and Erdman Junior (1982). The phytic phosphorus content was determined by the colorimetric method according to Chen, Toribara, and Warner (1956). A 3.55 factor, referring to the $28.2 \%$ content of phosphorus in the molecule of phytic acid was used to convert the phytic phosphorus in phytic acid. The reading was performed in UV-VIS spectrophotometer (Cintra, 20 ) at $820 \mathrm{~nm}$ using a calibration curve in the range of 0.9 to $9.0 \mu \mathrm{g}$ of phosphorus.

\subsection{Statistical analysis}

The results of color and water activity were assessed by regression analysis considering the cultivar and the roasting time as sources of variation. The regression graphs were obtained by the Statistica 7.0 software (STATSOFT, 2007). All analyses were performed in triplicate, and the means were compared by the Tukey test $(\mathrm{p} \leq 0.05)$. The results of the difference from control test were evaluated by ANOVA, and the means were compared by Dunnett's test $(\mathrm{p} \leq 0.05)$. The results of the free-choice profile analysis were evaluated by the Generalized Procrustes Analysis (GPA) using the Senstools software, version 2.3 (OP\&P..., 1998).
Replicated assessment of the samples by each assessor were included as data providing 10 individual matrices (one for each panelist), each with 21 rows ( 7 samples and 3 repllicates) and a different number of columns, varying from 7 to 11 according to the number of descriptors used by each panelist.

\section{Results and discussion}

\subsection{Physical properties}

The IRGA 417 raw bran showed lighter color compared to that of the BRS Primavera and BRS Sertaneja. The roasting process caused significant $(p \leq 0.05)$ changes in the lightness of the rice bran, but there was variation among the cultivars showing that differences in the grain morphology and chemical composition are associated with the roasting process. The longer the roasting time, the darker the bran (Figure 1). The intensity in yellow and red color (parameters $\mathrm{a}^{\star}$ and $\mathrm{b}^{\star}$ ) did not differ comparing roasting times for the three cultivars (data not shown).

After 18 minutes of roasting, the roasted rice bran of BRS Sertaneja got darker compared to the other cultivars. The raw bran Sertaneja BRS showed higher content of protein and reducing sugars (Table 1), which may be due to greater reduction in brightness during the roasting process resulting from the development of the Maillard reaction. Caramelization was another reaction that probably took place during bran roasting (ABDUL-HAMID et al., 2007).

The raw bran had Aw around $0.54 \pm 0.03$. After roasting, there was a significant $(\mathrm{p} \leq 0.05)$ reduction to $0.25 \pm 0.0$; therefore, its shelf-life can be prolonged. Water activity below 0.30 reaches the primary adsorption zone, where water molecules may be linked to groups such as carboxyl (COOH), which links to other water molecules by hydrogen bonds. This water layer would cover the food, but it would not dissolve the food components, which could lead to acceleration of lipids oxidation.

\subsection{Sensory evaluation}

For the three cultivars, there were observed difference ( $\mathrm{p} \leq 0.05)$ among the roasting times in the difference from control test. Approximately, $17 \%$ of the panelists stated that the rice bran samples roasted for 18 minutes had an unpleasant burn flavor, and $12 \%$ reported that the 6 minutes roasted samples had a characteristic flavor of raw bran. Other panelists (7\%) also pointed that the 12 minutes roasted IRGA 417 presented a pleasant sweet and roasted-like aroma. Based on these results, the Free-Choice Profile analysis was performed in the bran samples of the three cultivars roasted for 9 and 15 minutes roasted brans and the IRGA 417, roasted for 12 minutes.

In the sample consensus plot, the first dimension accounted for $65 \%$ of explanation and the second for $4 \%$ (Figure $2 \mathrm{a}$ ). The samples of roasted rice bran were well-characterized, and the explained variance (69\%) was higher than usual for the FreeChoice Profile analysis data (CALEGUER; BENASSI, 2007; THAMKE; DURRSCHMID; ROHM, 2009) indicating a good 

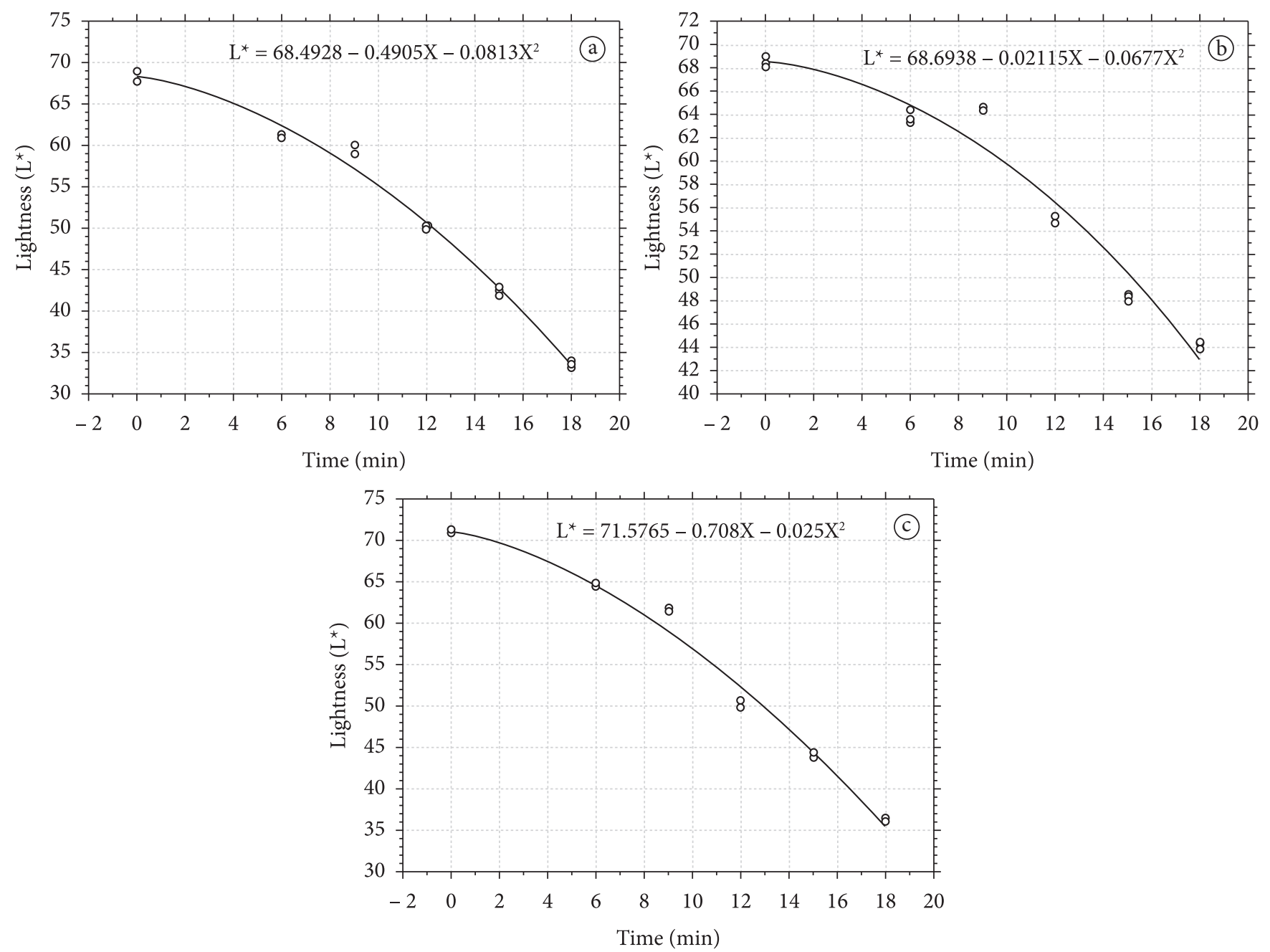

Figure 1. Lightness $\left(L^{*}\right)$ of bran from BRS Sertaneja (a), BRS Primavera (b), and IRGA 417 (c) concerning toasting time (minutes).
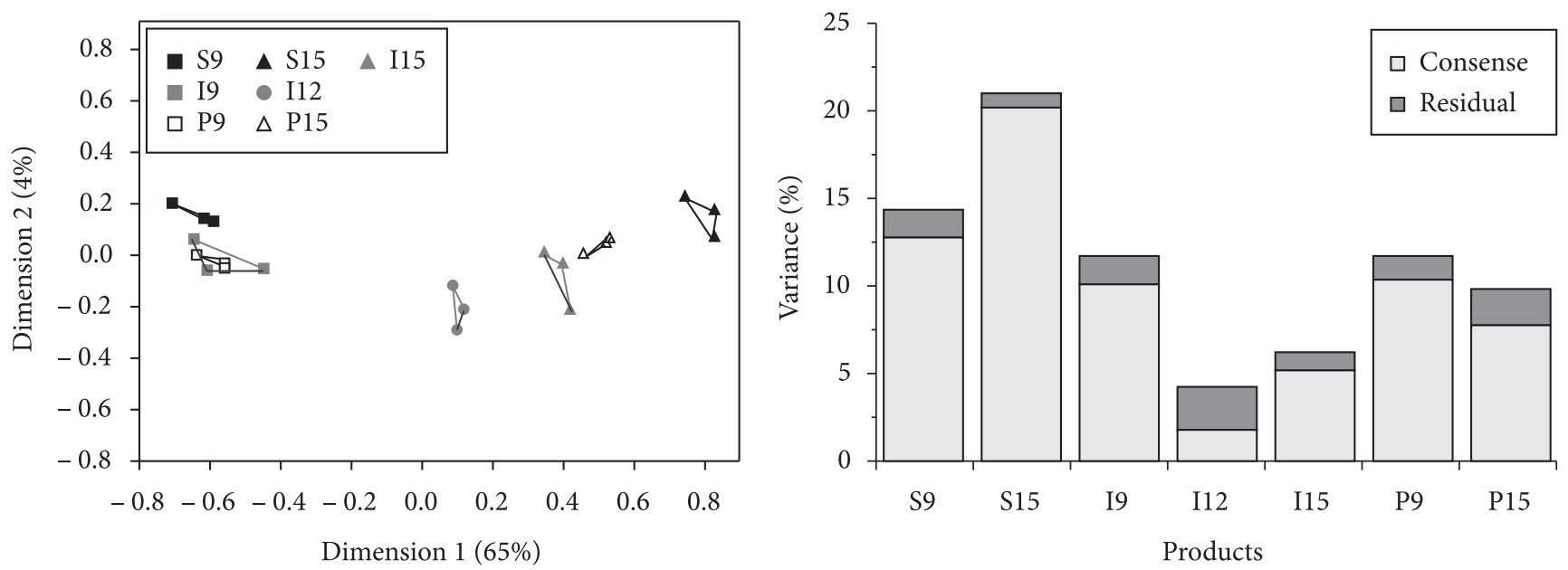

Figure 2. Two-dimensional consensus plot (a) and distribution of variance (b) for the samples: S15: BRS Sertaneja with 15 minutes roasting, S9: BRS Sertaneja roasted for 9 minutes, I9: IRGA 417 roasted for 9 minutes, I12: IRGA 417 roasted for 12 minutes, I15: IRGA 417 roasted for 15 minutes, P9: BRS Primavera roasted for 9 minutes, and P15: BRS Primavera roasted for 15 minutes. 
consensus among the panelists. Good repeatability, represented by the small size of triangles for each sample (Figure $2 a$ ), was also be observed. As a criterion, the sample descriptions were based on the descriptors used by the majority of the panelists and whose correlation results obtained GPA analysis were $>0.6$ (data not shown).

Dimension 1, associated to the roasting process intensity, was explained in the positive direction by the attributes of color (caramel, brown), aroma (burned, roasted), and taste (roasted, burnt, caramel), which had a high correlation for all panelists. The samples (S15, P15, and I15) with high roasting time (15 minutes) were allocated to the right side of the plot. The samples of lower roasting time were allocated to the left side and I12 in the center of the plot.

Dimension 2 was less important for the discrimination and was correlated with the attributes of sweet (positively) and bitter taste (negatively). This dimension contributed to the differentiation of the cultivars (BRS Sertaneja compared to IRGA 417 and BRS Primavera), especially at the initial time of roasting process (Figure $2 \mathrm{a}$ ).

The rice bran samples of BRS Sertaneja cultivar were discriminated from the others (Figure 2a) and showed a higher consensus (Figure 2b). The S15 sample was characterized by greater intensity of burned and roasted taste and roasted aroma than those of other cultivars with the same degree of roasting. S9 sample, also discriminated from P9 and I9, was characterized by presenting more intense aroma and flavor of raw rice than that of P9 and I9.

Rice bran samples from cultivars IRGA 417 and BRS Primavera were characterized as presenting more similar sensory characteristics (Figure 2a). In general, the samples of cultivar IRA 417 were described by the panelists as having sweet taste and aroma, even those from longer roasting times (I12 and I15).

\subsection{Chemical characteristics}

All raw rice bran samples showed high levels ( $\mathrm{p} \leq 0.05)$ of protein, lipid, insoluble dietary fiber, total dietary fiber, carbohydrates, total phosphorus, phytic phosphorus, and phytic acid. After the roasting process, the rice bran samples from the three cultivars showed lower ( $\mathrm{p} \leq 0.05)$ moisture, protein, lipids, carbohydrates, total phosphorus, phosphorus acid, and phytic acid content (Table 1).

The loss of moisture was caused by its evaporation during the heat treatment. The microwave roasting process probably accounts for the conservation of rice bran during storage due to decreased water activity keeping the quality for longer periods. The moisture differences between the cultivars (Table 1) may be caused by differences in the bran chemical composition, which affects the ability to retain water during the roasting process. The fibers have high water holding capacity (CAUVAIN; YOUNG, 2002). After 15 minutes of roasting, rice bran samples of IRGA 417 , which showed lower levels $(\mathrm{p} \leq 0.05)$ of total dietary fiber at time 0 and lower moisture content, retained less moisture content increasing the total dietary fiber content (Table 1).
IRGA 417 rice bran samples showed higher $(\mathrm{p} \leq 0.05)$ ash content than that of the others before and after the roasting process (Table 1). IRGA 417 cultivar is classified as irrigated and BRS Sertaneja and BRS Primavera as highland; and according to the literature, the ash content and the cultivar depend on handling, climate, and geographic location of the rice crop (KRISHNARAO; MUKUND; CHAKRABORTY, 1991).

Protein content was higher for the raw bran samples than for the roasted samples $(\mathrm{p} \leq 0.05)$ (Table 1). The differences in protein content among the rice bran samples of the cultivars studied before and after the roasting process, can be explained by the development of Maillard reaction during heat treatment, which consists of a complex chain of chemical reactions involving reducing sugars and proteins or amino acids accountable for the formation of volatile compounds, and melanoidins among others (RUFIÁN-HENARES; MORALES, 2007). There is also the formation of bitter compounds and reduced nutritional value resulting from the loss of certain amino acids such as lysine due to its use in the first stage of the Maillard reaction (MARTINS; JONGEN; VAN BOEKEL, 2000). Amissah et al. (2003) found protein levels in sixteen varieties of raw rice bran ranging from 11.53 to $15.35 \mathrm{~g}(100 \mathrm{~g})^{-1}$. Silva, Sanches and Amante (2006) found values close to those obtained in this work for roasted rice bran $\left[17.5 \mathrm{~g}(100 \mathrm{~g})^{-1}\right]$.

In the rice bran samples, regardless of the cultivar, there was first an increase and then a decrease in lipid content during the course of the roasting process (Table 1). The increase could be explained by the disruption of possible complexes between lipids-proteins and/or carbohydrates-lipids, as shorter heating periods may undo weaker interactions. However, there was a lower lipid content in the rice bran roasted for 15 minutes compared with the content of raw rice bran, which could be explained by the short hydrolysis and decomposition of triacylglycerides with consequent release of fatty acids and formation of volatile compounds accountable for the aroma after a longer roasting time. The raw rice bran samples analyzed in the present study showed lipid content close to the that reported by Ramezanzadeh et al. (2000) and Feddern, Furlong and Soares

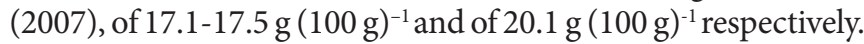
The rice bran submitted to the roasting process in this study showed lower value of lipids than those found by Silva, Sanches and Amante (2006) (28.08 g $\left.(100 \mathrm{~g})^{-1}\right)$.

There were increased $(\mathrm{p} \leq 0.05)$ levels of soluble, insoluble, and total dietary fiber in roasted rice bran samples, regardless of the cultivar (Table 1); possibly due to the formation of insoluble aggregates with the loss of water due to the roasting process (DUODU et al., 2003). In contrast, the levels of reducing sugars decreased during the roasting process (Table 1) since glucose is consumed in the Maillard Reaction and in caramelization during the process. The BRS Sertaneja raw rice bran showed higher content of reducing sugars, which may have influenced the darkening (lower lightness value) of this cultivar during the roasting process (Figure 1).

Studies have shown that phytic acid is a structure capable of chelating minerals such as calcium, zinc, and iron. It has antioxidant effect (ZHOU et al., 2003) and combines with protein and starch resulting in reduced bioavailability of these 
Table 1. Chemical composition of raw and toasted rice bran of cultivars BRS Sertaneja, BRS Primavera, and IRGA 417 concerning roasting time. ${ }^{1}$

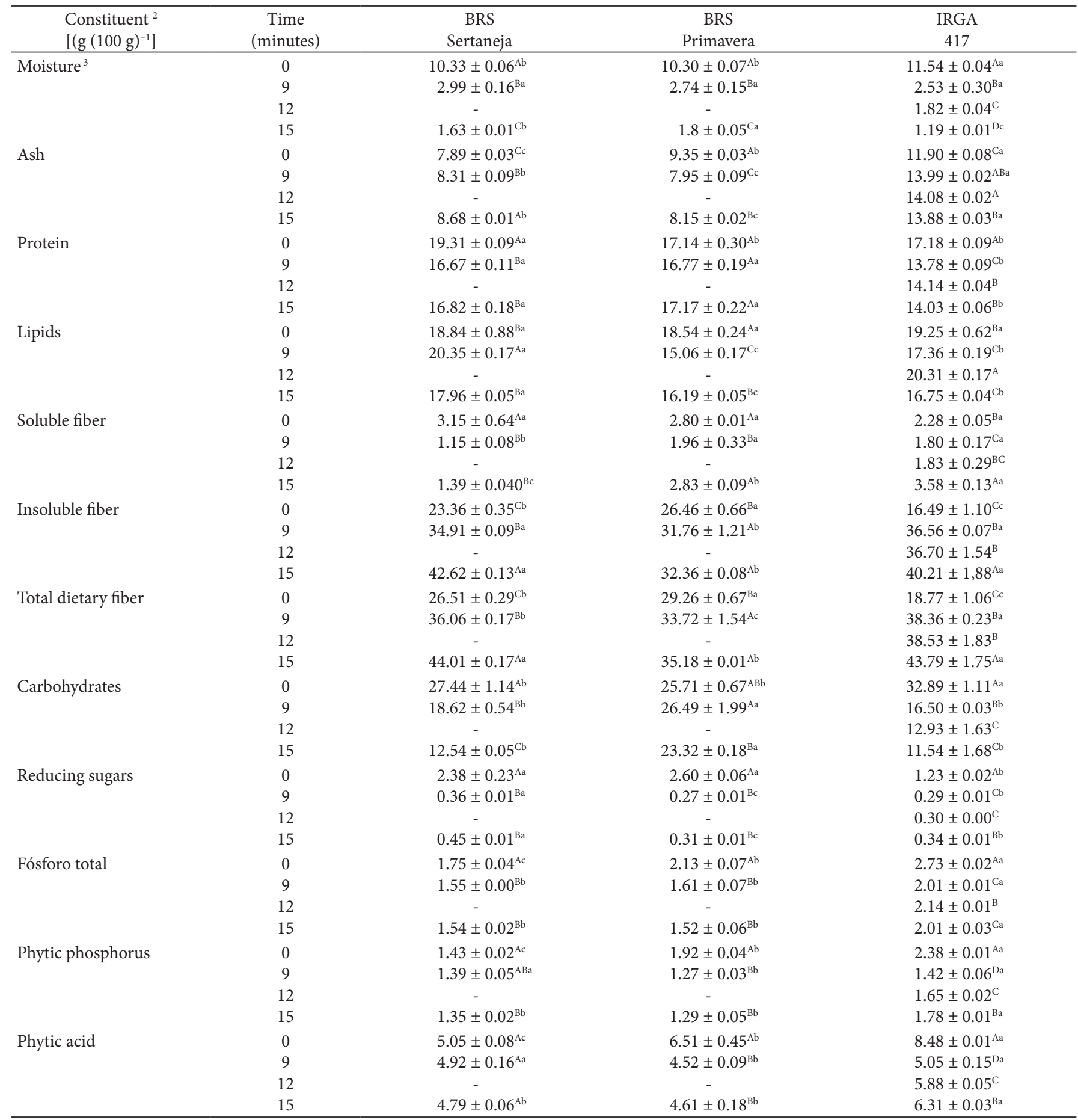

${ }^{1}$ Mean in triplicate $\pm \mathrm{SD}$. ${ }^{2}$ Different letters in the same row indicate differences between formulations (Tukey, $\mathrm{p} \leq 0.05$ ); ${ }^{3}$ Moisture on a wet basis and other components on a dry basis.

nutrients in the body (OATWAY; VASANTHAN; HELM, 2001). IRGA 417 rice bran showed the highest ( $\mathrm{p} \leq 0.05$ ) content of total phosphorus before and after roasting for 9 and 15 minutes, followed by BRS Sertaneja and BRS Primavera rice bran (Table 1). The total phosphorus found in vegetables is composed of organic and inorganic phosphorus, which is represented by the phytic acid molecule. The phytic acid or myo- inositol hexaphosphate $\left(\mathrm{C}_{6} \mathrm{H}_{18} \mathrm{O}_{24} \mathrm{P}_{6}\right)$ is a natural component of every seed constituting $1-3 \%$ of the weight in legumes and cereals, which accounts for 60 to $90 \%$ of the total phosphorus (O'DELL; DEBOLLAND; KOIRTYOHANN, 1972). The lower content of total phosphorus in roasted bran compared to raw bran can be explained by the fact that there was a reduction of phytic phosphorus during the roasting process thus reducing the total phosphorus. 
In this study it was found higher $(\mathrm{p} \leq 0.05)$ content of phytic phosphorus and consequently higher content of phytic acid in raw rice bran compared to that of the roasted bran; this fact can be explained due to the degradation of phytic acid forming complexes with proteins and carbohydrates thus hindering protein and amino acids digestibility. Sharma, Chauhan and Agrawal (2004) reported phytic acid values of $2.93 \mathrm{~g}(100 \mathrm{~g})^{-1}$, $2.45 \mathrm{~g}(100 \mathrm{~g})^{-1}$ and $2.46 \mathrm{~g}(100 \mathrm{~g})^{-1}$ for raw rice bran stabilized by oven and extruded, respectively; levels lower than those observed in this study. Most antinutritional factors found in rice bran (trypsin inhibitor, lectins, and phytic acid) are inactivated by heat and form insoluble complexes (OATWAY; VASANTHAN; HELM, 2001), which explains the lower content of phytic acid in roasted bran compared to that of raw bran.

\section{Conclusion}

The roasting process affects the physical, chemical, and sensory characteristics of rice bran. Free-Choice Profile analysis allowed the differentiation of rice bran samples in terms the cultivar and roasting time. The IRGA 417 bran roasted for 12 minutes presented the sweet taste and aroma, desirable characteristics of roasted bran. The roasting process reduced the contents of reducing sugars, total phosphorus, phytic phosphorus, and phytic acid in rice bran for the three cultivars analyzed. The roasted rice bran samples, regardless of cultivar, had high levels of proteins, lipids, and insoluble dietary fiber showing potential for use as a functional ingredient.

\section{References}

ABDUL-HAMID, A. et al. Preliminary study of the chemical composition of the rice milling fractions stabilized by microwave heating. Journal of Food Composition and Analysis, v. 20, p. 627 637, 2007. http://dx.doi.org/10.1016/j.jfca.2007.01.005

AMISSAH, J. G. N. et al. Nutrient composition of bran from new rice varieties under study in Ghana. Food Control, v. 14, p. 21-24, 2003. http://dx.doi.org/10.1016/S0956-7135(02)00047-6

ASSOCIATION OF OFFICIAL ANALYTICAL CHEMISTS - AOAC. Official methods of analysis of AOAC International: Agricultural chemicals, contaminants, drugs. 16th ed. Gaithersburg: AOAC International, 1997. v. 1.

BRASIL. Ministério da Saúde. Agência Nacional de Vigilância Sanitária - ANVISA. Resolução RDC n 360, de 23 de dezembro de 2003. Regulamento Técnico sobre Rotulagem Nutricional de Alimentos Embalados, tornando obrigatória a rotulagem nutricional. Diário Oficial da República Federativa do Brasil, Brasília, DF, dez. 2003. Disponível em: <http://www.anvisa.gov. br/e-legis/>. Acesso em: 20 maio 2009.

CALEGUER, V. D.; BENASSI, M. T. Efeito da adição de polpa, carboximetilcelulose e goma arábica nas características sensoriais e aceitação de preparados em pó para refresco sabor laranja. Ciência e Tecnologia de Alimentos, v. 27, p. 270-277, 2007. http://dx.doi. org/10.1590/S0101-20612007000200010

CAUVAIN, S. P.; YOUNG, L. S. Fabricación de pan. Zaragoza: Editorial Acribia, 2002. 440 p.

CHEN, P. S.; TORIBARA, T. Y.; WARNER, H. Microdetermination of phosphorus. Analytical Chemistry, v. 28, p. 1756-1758, 1956. http://dx.doi.org/10.1021/ac60119a033
DUODU, K. G. et al. Factors affecting sorghum protein digestibility. Journal of Cereal Science, v. 38, p. 117-131, 2003. http://dx.doi. org/10.1016/S0733-5210(03)00016-X

FEDDERN, V.; FURLONG, E. B.; SOARES, L. A. S. Efeitos da fermentação nas propriedades físico-químicas e nutricionais do farelo de arroz. Ciência e Tecnologia de Alimentos, v. 24, p. 800804, 2007. http://dx.doi.org/10.1590/S0101-20612007000400020

HAN, O. et al. Inositol phosphates inhibit uptake and trans-port of iron and zinc by human intestinal cell line. Journal of Nutrition, v. 124, p. $580-587,1994$.

KITZBERGER, C. S. G. et al. Caracterização sensorial de cafés arábica de diferentes cultivares produzidos nas mesmas condições edafoclimáticas. Brazilian Journal of Food Technology, p. 3948, 2010. Volume especial.

KRISHNARAO, V. K.; MUKUND, M. M.; CHAKRABORTY, P. G. I. Direct pyrolysis of raw husks for maximization of silicon carbide whisker formation. Journal of the American Chemical Society, v. 74, p. 2869-2875, 1991.

MARTINS, S. I. F. S.; JONGEN, W. M. F.; VAN BOEKEL, M. A. J. S. A review of Maillard reaction in food and implications to kinetic modelling. Trends in Food Science and Technology, v. 11, p. 364373, 2000. http://dx.doi.org/10.1016/S0924-2244(01)00022-X

MOSKOWITZ, H. R. Product testing and sensory evalution of foods. Westport: Food e Nutrition Press, 1983. 605 p.

MURRAY, J.; DELAHUNTY, C. M.; BAXTER, I. A. Descriptive sensory analysis; past, present and future. Food Research International, v. 34, p. 461-471, 2001. http://dx.doi.org/10.1016/ S0963-9969(01)00070-9

NELSON, N. A fotometric adaptaion of Somogyi method for the determination of glucose. Journal of Biological Chemistry, v. 153, p. 375-380, 1944.

O'DELL, B. L.; DEBOLLAND, A. R.; KOIRTYOHANN, S. R. Distribution of phytate and nutritionally important elements among the morphological components of cereal grains. Journal of Agricultural and Food Chemistry, v. 20, p. 718-721, 1972. http:// dx.doi.org/10.1021/jf60181a021

OATWAY, L.; VASANTHAN, T.; HELM, J. H. Phytic acid. Food Reviews International, v. 17, p. 419-431, 2001. http://dx.doi. org/10.1081/FRI-100108531

OP\&P PRODUCT RESEARCH. Senstools versão 2.3. Ultrecht: OP\&P. Product Research, 1995-1998. Conjunto de programas. CD ROOM.

PARRADO, J. et al. Preparation of a rice bran enzymatic extract with potential use as functional food. Food Chemistry, v. 98, p. 742748, 2006. http://dx.doi.org/10.1016/j.foodchem.2005.07.016

RAMEZANZADEH, F. M. et al. Effects of microwave heat, packaging, and storage temperature on fatty acid and proximate compositions in rice bran. Journal of Agriculture and Food Chemistry, v. 48, p. 464-467, 2000. http://dx.doi.org/10.1021/jf9909609

RUFIÁN-HENARES, J. A.; MORALES, F. J. Effect of in vitro enzymatic digestion on antioxidant activity of coffee melanoidins and fractions. Journal of Agricultural and Food Chemistry, v. 55, p. 1001610021, 2007. http://dx.doi.org/10.1021/jf0718291

SAUNDERS, R. M. The properties of rice bran as a foodstuff. Cereal Foods World, v. 35, p. 632-636, 1990.

SHARMA, H. R.; CHAUHAN, G. S.; AGRAWAL, K. Physcio-chemical characteristics of rice bran processed by dry heating and extrusion 
cooking. International Journal of Food Properties, v. 7, p. 603614, 2004. http://dx.doi.org/10.1081/JFP-200033047

SILVA, M. A.; SANCHES, C.; AMANTE, E. R. Prevention of hydrolytic rancidity in rice bran. Journal of Food Engineering, v. 75, p. 487491, 2006. http://dx.doi.org/10.1016/j.jfoodeng.2005.03.066

SOMOGYI, M. A new reagent for determination of sugars. A New Sugar Reagent, v. 160, p. 61-68, 1945.

STATSOFT. Statistica 7.0 for Windows - Computar program manual. Tulsa: Statsoft, Inc., 2007. CD ROOM.
THAMKE, I.; DURRSCHMID, K.; ROHM, H. Sensory description of dark chocolates by consumers. Food Science and Technology, v. 42, p. 534-539, 2009.

THOMPSON, D. B.; ERDMAN JUNIOR, J. W. Phytic acid in soybeans. Journal of Food Science, v. 47, p. 513-517, 1982. http://dx.doi. org/10.1111/j.1365-2621.1982.tb10114.x

ZHOU, Z. et al. Fatty acid composition of three rice varieties following storage. Journal of Cereal Science, v. 37, p. 327-335, 2003. http:// dx.doi.org/10.1006/jcrs.2002.0502 